\title{
Virtual Reality and Mixed Reality Education: A Solution for Today's Education in a Circular Bioeconomy $^{\dagger}$
}

\author{
Marilena Gabriela Zaharie ${ }^{1}$, Mihai Caramihai 2,*, Montserrat Adroguer ${ }^{3}$, Paqui Blánquez ${ }^{3}$, \\ Tom Kuppens ${ }^{4}$ and Nicoleta Radu ${ }^{1,5}$
}

1 Biotechnology Dept, University of Agronomic Sciences and Veterinary Medicine of Bucharest, 59 Mărăşti Boulevard, District 1, Bucharest 011464, Romania; gabrielazaharie76@gmail.com

2 Faculty of Automatic Control and Computers, Politehnica University of Bucharest, 313 Splaiul Independentei Street, District 6, Bucharest 060042, Romania

3 Department of chemical, Biological and Environmental Engineering, School of Engineering, Campus Bellaterra, 08193 Cerdanyola del Vallès (Barcelona), Spain; montserrat.sarra@uab.cat (M.A.); paqui.blanquez@uab.cat (P.B.)

4 Universiteit Hasselt Campus Campus Hasselt, 423500 Martelarenlaan, Belgium; tom.kuppens@uhasselt.be

5 National Institute of Chemistry \& Petrochemistry R\&D of Bucharest, INCDCP 202 Splaiul Independentei Street, District 6, Bucharest 060021, Romania; nicolbiotec@yahoo.com

* Correspondence: m.caramihai@yahoo.com

+ Presented at the International Symposium "Priorities of Chemistry for A Sustainable Development" Priorichem, Bucharest, 28-30 October 2020.

Published: 11 November 2020

Keywords: virtual reality; mixed reality; circular bioeconomy

\section{Introduction}

The updated strategy and action plan for the bioeconomy of October 2018 is part of the European Commission's strategy to make efficient use of natural resources, to stimulate jobs, growth and investment. It aims to improve and expand the sustainable use of renewable resources to address global and local challenges, such as climate change and sustainable development. Ergo, the European Commission (EC) introduces a new direction of integrated development of the bioeconomy-a circular bioeconomy with bio-based products. A circular bioeconomy is defined as an "intersection of the circular economy (restorative, regenerative economic model, in which nothing is lost and everything fuels a new cycle, and waste is treated as a resource) and bioeconomy (obtaining biobased products and services)".

\section{Material and Methods}

In order to educate students and postgraduate students in this new, high-level complex and advanced technological field imposes a sophisticated up to date education methodology based on online learning and more Virtual Reality (VR) or Mixed Reality (MR) [1]. VR will play an important role in training students and introducing difficult concepts that are easier to explain through strategic experiences in a virtual environment. VR/MR can deliver learning experiences that no longer depend on lectures to teach concepts or the idea of earning a degree to attain just one role in the course of a person's lifelong career [2]. In fact, VR can contribute to the creation of learning experiences which extend into several disciplines facilitating the development of multidisciplinary careers, and this is in line with the educational needs imposed by the circular, multidisciplinary and interdisciplinary bioeconomy par excellence. Students can benefit from quasi-real scenarios that will prepare them for real life/various concrete tasks at work. As technology progresses, the best way to explain abstract 
concepts is through direct demonstration, rather than through ex-cathedra theoretical lectures [3-6]. With the help of VR, study tools can be adapted to allow students to learn at their own pace and provide learning experiences that lead to a better mastery of information and a deeper understanding of it.

\section{Result and Discussion}

The obtained results were focused on: (a) Documentation (technical and pedagogical literature, education curricula and contents, training projects, technical and pedagogical papers) for the elaboration of the Curriculum and Content in sustainable Circular Bioeconomy (CB); (b) realization of a review study with the recommended MR methods to be chosen and applied; (c) integration of MR methodology to elaborate on the $\mathrm{CB}$ by using these methods. The innovative character of all teaching materials is that they are centered on competence formation to perform in $\mathrm{CB}$, an outstanding technological and economic domain. The main competences that need to be modeled are integrative knowledge, system thinking, ethics and values, action, communication and reflection capacity, vision, planning and organizing potential, and networking ability. Finally, the students should actively and independently develop the educational skills that will allow them to process, organize, understand, and evaluate scientific information and to become lifelong self-directed learners by using VR/MR methodology for training/learning.

\section{Conclusions}

Due to the fact that CB is still in its infancy, a new industrial paradigm needs to be built in the European Union (EU) in the coming decades. As a major consequence, the role of education in training future specialists is predominant, and curricula and curricula, especially in universities, need to be elaborated in relation to new information technologies. At the same time, in order to educate postgraduate students in this complex and advanced technological field, an updated education methodology based on online learning requires a focus on virtual reality (VR) and mixed reality (MR).

Acknowledgments: This work was supported from the Program entitled: Cooperation for innovation and the exchange of good practices. Strategic Partnerships for Higher Education. Project No: 2019-1-RO01-KA203-063773.

\section{References}

1. Farshid, M.; Paschen, J.; Eriksson, T.; Kietzmann, J. Go boldly!: Explore augmented reality (AR), virtual reality (VR), and mixed reality (MR) for business. Bus. Horiz. 2018, 64, 657-663. doi:10.1016/j.bushor.2018.05.009.

2. Minaudo, M. Augmented, Virtual, Mixed Reality (AR/VR/MR) and New Fields of Application. In Proceeding of the International Congress on Immersive Technologies and New Professions in 21 Century, Palermo, Italy, 13 December 2019. doi:10.13140/RG.2.2.33909.52960.

3. Microsoft Documentation, Get started with Mixed Reality, July 2020. Available online: https:/docs.microsoft.com/en-us/windows/mixed-reality/get-started-with-mr\#understand-the-basics (accessed on 28 September 2020).

4. Radu, N.; Chirvase, A.A.; Babeanu, N.; Popa, O.; Hastaran, F.; Velykiene, B. Education management in the field of life sciences-skills needed to start and develop an innovative SME. Sci. Pap. Ser. Manag. Econ. Eng. Agric. Rural Dev. 2018, 18, 375-382.

5. Radu, N.; Chirvase, A.A.; Babeanu, N.; Popa, O. Educational management in the field of life sciencesblending learning for bioentrepreneurs training. Sci. Pap. Ser. Manag. Econ. Eng. Agric. Rural Dev. 2015, 15, 301-304. 
6. Radu, N.; Chirvase, A.A.; Babeanu, N.; Popa, O.; Caramihai, M.D. Studies regarding personal skills needed in entrepreneurship. Case study in France, Lithuania and Romania. Sci. Pap. Ser. Manag. Econ. Eng. Agric. Rural Dev. 2020, 20, 403-408.

Publisher's Note: MDPI stays neutral with regard to jurisdictional claims in published maps and institutional affiliations.

(C) 2020 by the authors. Licensee MDPI, Basel, Switzerland. This article is an open access article distributed under the terms and conditions of the Creative Commons Attribution (CC BY) license (http://creativecommons.org/licenses/by/4.0/). 